self image, level of aspiration and self-control. In situations of pedagogical interaction, reflection is not merely a focus on self, but a means of knowing and objectifying the image of a student, which is perceived as a holistic personality.

Key words: reflection, reflexive skills, teacher, pedagogical activity, self-knowledge, selfexamination, professional training, professional self-improvement.

УДК 316.61-053

O. I. APTEMOBA

DOI: https://doi.org/10.35619/prap rv.vi12.39

\title{
СОЦАЛЬНО-ПСИХОЛОГІЧНІ ЧИННИКИ ВХОДЖЕННЯ МОЛОДІ У СУБКУЛЬТУРНИЙ ПРОСТІР
}

У статті здійснено теоретичний аналіз сочіально-психологічних чинників входження молоді y субкультурний простір, впливу молодіжних субкультур на формування особистості, наголошується на необхідності розробки $і$ впровадження програм сочіалізаиіі молоді, в яких враховувавався б вилив субкультурного простору.

Ключові слова: молодіжна субкультура, субкультурний простір, девіантна поведінка, сочіально-психологічні чинники.

В статье осуществлен теоретический анализ социально-психологических факторов вхождения молодежи в субкультурное пространство, влияния молодежных субкультур на формирование личности, акцентируется внимание на необходимости разработки и внедрения программ сочиализачии молодежи, в которых учитывалось бы влияние субкультурного пространства.

Ключевые слова: молодежная субкультура, субкультурное пространство, девиантное поведение, сочиально-психологические факторы.

Постановка проблеми. Молодь $є$ рушійною силою розвитку суспільства, іiі стратегічним ресурсом, одним із визначальних чинників громадсько-політичного та соціально-економічного життя країни. 3 іншої сторони, молоді люди, які не сформували в собі систему цінностей, мають нестійкий світогляд, дуже часто піддаються впливам, знецінюють ідеали, не можуть знайти свого місця в житті, свою адекватну соціальну групу, реалізувати себе, а тому знаходять вирішення своїх проблем в молодіжних субкультурах. Молодіжна субкультура - це певне поле реалізації, що виникає як потреба у молодих людей, яке вони обирають при відсутності альтернативи. Тому дуже важливо вивчення різних молодіжних субкультур з метою визначення ефективного комплексу заходів профілактики девіантної та делінкветної поведінки молодих людей в неформальних об'єднаннях. Це дає підстави вченим посилити дослідження соціально-психологічних чинників входження молоді у субкультурний простір і активізувати пошуки ефективних шляхів попередження і подолання негативних проявів у молодіжному середовищі.

Аналіз останніх досліджень і публікацій. Увага вчених до проблеми молодіжних субкультур та їх впливу на розвиток особистості інтенсифікувалася з середини 80 -х років минулого століття, коли послабився загальний ідеологічний тиск, почали руйнуватися старі організаційні форми i молодь отримала можливість більш вільно заявляти про свої уподобання, обирати форми особистісного самовияву. Проблемі впливу молодіжних субкультур на формування особистості присвячені дослідження багатьох сучасних вітчизняних i зарубіжних психологів, зокрема Л. С. Алексеєва, І. П. Башкатова, М. О. Белашова, С.А.Бєлічева, В.Г. Бочарова, Л. П. Буєва, Ю.В. Грищук, В. Г. Деєва, Л. Д. Заграй, І. С. Кона, Т.В. Кравченко, Н.Ф Кузнецова, Ю.О. Лисенко, Ю. М. Мельника, В. І. Мироненко, В. Р. Павелківа, Б.Д. Паригіна, О. С. Товканець, А.М. Яковлева та ін. Особливо увага акцентується на психолого-педагогічних особливостях учасників молодіжних об'єднань, їх протидія існуючій системі, анархії, несправедливості.

Актуальними на сьогоднішній день залишаються питання асоціальної поведінки молоді. Теоретико-методологічні дослідження в цьому напрямі представлені роботами А. Адлера, Ю. К. Александрова, Ю.М.Антоняна, О. Бандури, А.Басса, І.П.Башкатова, З. Берковіц, Дж. Брауна, Ф.Д.Кадарія, П. Кауфман, Ю.В. Лазарєва, С.Я.Лебедєва, К. Левіна, К. Лоренца, М.Мюррей, А.В.Петряніна, В.Ф. Пирожкова, К. Річарда, Р.Уолтера, 3. Фрейда, Е. Фромма, І.О. Фурманова, М. В. Шакурової та ін. В основному вони висвітлювали питання становлення та діяльність підліткових субкультур, вплив субкультур на формування особистості в підлітковому віці, 
виникнення агресії під впливом субкультур, вплив субкультур на формування девіацій у підлітків, місце молоді у кримінальних субкультурах.

Формулювання цілей статті. У цій статті ставимо за мету дослідити соціально-психологічні чинники входження молоді у субкультурний простір і активізувати пошуки ефективних шляхів попередження і подолання негативних проявів у молодіжному середовищі, оскільки це питання впродовж останніх років набуває особливої актуальності і $€$ поки що маловивченим.

Виклад основного матеріалу досліджень. Молодіжних субкультур у світі існує велика кількість, і вони, як соціально-психологічні явища, здатні виконувати як позитивні, так і негативні функції щодо суспільства загалом та становленні і розвитку особистості зокрема. Сам науковий термін «субкультура» 3'явився приблизно в 30-х роках XX століття, який поєднав у собі такі поняття, як «богема», «люди одного кола», «золота молодь». У психолого-педагогічній науці при поясненні субкультури увага, насамперед, зосереджується на системі цінностей, установок, способів поведінки і життєвих стилів певної соціальної групи, яка відрізняється від пануючої, домінуючої в суспільстві культури, хоча і пов'язана з нею [2, с. 11]. За даними досліджень в Україні лише 2-3\% молоді перебувають в офіційно зареєстрованих молодіжних організаціях і понад $26 \%$ - у неформальних угрупуваннях. На сучасному етапі, коли загострюються не лише загальносоціальні, але й специфічні молодіжні проблеми, як наголошують психологи, відбувається зміна традиційних моделей соціалізації, актуалізується пошук нових ефективних способів соціалізуючого й адаптаційного впливу [2, с. 7]. Субкультура - це поняття, яке можна розглядати як сукупність деяких негативно інтерпретованих норм і цінностей традиційної культури, що функціонує в якості культури певного прошарку суспільства; як особливу форму організації людей (частіше всього молоді), автономне цілісне утворення усередині панівної культури, що визначає стиль життя і мислення іії носіїв, що відрізняється своїми звичаями, нормами, комплексами цінностей і навіть інститутами; як трансформовану професійним мисленням систему цінностей традиційної культури, що отримала своєрідне світоглядне забарвлення [5, с.170]. У психолого-педагогічному аспекті молодіжну субкультуру можна розглядати з позиції появи, формування та функціонування неформальних молодіжних об'єднань, роботу педагогів та психологів як спеціалістів групи підтримки 3 ними. Узагальнення результатів досліджень учених дозволяє виокремити деякі характеристики молодіжної субкультури. Так, головною характерною особливістю молодіжної субкультури є ¥ї відстороненість, часто демонстративність, епатажність що відрізняється від культурних цінностей старших поколінь, національних традицій. У масовій свідомості сприйняття молодіжної субкультури часто має негативний характер. На цьому тлі молодіжна субкультура зі своїми специфічними ідеалами, модою, мовою, мистецтвом все частіше помилково оцінюється як контркультура. Іншою характерною особливістю сучасної молодіжної субкультури є переважання споживання над творчістю. Це дуже негативна особливість, тому що по-справжньому залучення до культурних цінностей відбувається тільки за активної самостійної культуротворчої діяльності. Третьою характерною особливістю молодіжної субкультури можна назвати іiі авангардність, спрямованість у майбутнє, часто екстремальність. Найчастіше ці риси поєднуються з відсутністю серйозного фундаменту історичних і культурних традицій. У молодіжному середовищі з'явилися нові тенденції в розумінні культури. Визнаючи об'єктивне існування історико-культурних цінностей, національних культурних традицій, молодь, тим не менш, не проявляє активності в їх освоєнні, вважаючи це проблемою другорядною, що не має практичної значущості в реальному соціально-політичному та історичному контексті, приділяє більше уваги іміджевим технологіям, які не мають глибоких культурних основ. Культура підміняється етикетом, зміст - формою. Неформальний молодіжний рух існує як стихійний, не керований державою процес, відокремлений і такий, що протистоїть реальній соціальній ситуації.

Умови життя в цілому створюють передумови для організації молоді в більш-менш великі групи, рухи, об'єднання, що є об'єднуючим чинником, який формує колективну свідомість, колективну відповідальність і загальні поняття соціально-культурних цінностей. Як свідчать результати наших досліджень, основною причиною виникнення неформальних молодіжних груп $\epsilon$ порушення процесу адаптації молодих людей у навколишньому соціальному середовищі. Сам факт появи цих груп - процес закономірний, оскільки в юнацькому віці виникає підвищена потреба у спілкуванні з однолітками, до думки яких молоді люди схильні прислухатися більше, ніж до думки дорослих. Проблема полягає в тому, що адаптована до соціального оточення молода людина вибирає соціально схвалювану групу однолітків для самореалізації, дезадаптовані - асоціальну. Більшість молодих людей об'єднуються в угрупування різної асоціальної спрямованості. Наші спостереження дозволяють виділити наступні причини, які спричиняють необхідність увійти в ту чи іншу неформальну молодіжну групу: потреба в друзях, з якими приємно і комфортно; прагнення пізнати незвичайне, в тому числі сучасне західне мистецтво; неуспішність у навчанні, байдужість до 
навчання і відчуження від одногрупників; відсутність інтересу до чогось, бездіяльність; потреба в сильних i незвичних емоційних враженнях; неувага до молодих людей i конфлікти в сім’і, бездоглядність, самотність, беззахисність; оригінальність вражень, одержуваних в групах; можливість проявити протест проти становища молоді в сучасних умовах. Дуже важливе значення для людини має сім’я. Руйнування сімейних цінностей, низька заробітна плата батьків, розшарування населення, підвищення агресивності та насилля в суспільстві - все це негативно позначається на формуванні свідомості підлітків та юнацтва [2, с.7]. Неформальні об'єднання і молодіжні рухи характеризуються певними функціями. Однією з головних серед них є можливість самореалізації, тобто суб'єктивного втілення. Дуже важлива інструментальна функція, коли група стає інструментом для досягнення свідомих чи несвідомих результатів, а також компенсаторна функція, яка пов'язана 3 відсутністю особистої незалежності й свободи в офіційних структурах, хоча незалежність у неформальних групах - уявна. Евристична функція виражає художньо-творчі й моральні прагнення молоді та реалізується в соціокультурній діяльності.

Отже, факторами, що сприяють виникненню молодіжних субкультур, є: неможливість самореалізації в колі сім'ї, в школі, інституті або формальних громадських організаціях, відсутність взаєморозуміння чи непорозуміння, розбіжності у поглядах з батьками та викладачами. Серед мотивів, що спонукають прагнення до відходу молоді в неформальні угруповання, об'єднання можна назвати такі, як бажання знайти однодумців, опинитися в середовищі собі подібних, отримати можливість спілкування та взаєморозуміння, відійти від самотності, заповнити свій вільний час, відійти від постійного нагляду батьків, учителів, протиставити силі суспільства колективну силу молодіжного об'єднання або групи [5, с.170]. При запереченні, неприйнятті форм дозвілля, пропонованих їм суспільством і державою, вони цілком задовольняються своїм альтернативним, часто асоціальним проведенням часу: дворовим, дискотечним, рок-тусовками, прогулянками по місту або переглядом гостросюжетних, позбавлених інтелектуального змісту боєвиків, супроводом «культових» музичних груп або спортивних команд і т.п. Прихильність молодих людей до насильства формується, з однієї сторони, принципами групи, з іншої - насильством по відношенню до дитини 3 боку батька або матері. Це породжує схильність вирішувати конфлікти силою.

Агресивні тенденції мають ряд специфічних рис і характерних особливостей. Перш за все, це критичне ставлення молодих людей і прагнення до заперечення або перегляду традиційних цінностей, часткова або повна відмова від існуючої офіційної ідеології, негативне ставлення до офіційної культури, традиційного мистецтва, орієнтація на власні ідеали, спосіб життя, цінності, характерні даній субкультурі, об'єднанню або групі. Учасниками цих утворень стають молоді люди, що виявилися не потрібні суспільству. Ці об'єднання відрізняються своєрідними атрибутами: своя ідеологія, спосіб життя, стиль музики, зовнішній вигляд, форма дозвілля, включаючи місця зустрічей.

У психолого-педагогічній літературі можна зустріти наступну типологізацію молодіжних субкультур: романтико-ескапістські субкультури (хіпі, індеаністи, толкієністи, 3 певним застереженням - байкери), гедоністично-розважальні (мажори, рейвери, ре-пери і т.п.), кримінальні (гопники, любери), анархо-нігілістичні (панки, екстремістські субкультури «лівого» і «правого» спрямування), які можна також назвати радикально-деструктивними [5, с. 171]. Особливо небезпечною $є$ субкультура тієї частини молоді, яка вживає різні психоактивні та наркотичні речовини. Зазначимо, що більшість молодих людей обирає традиційний шлях соціалізації, водночас, за даними наукових досліджень у субкультурний простір попадає до $58 \%$ молодих людей [3, с. 76]. Молодь знаходиться у процесі особистісного і професійного зростання, динамічного пошуку та визначення власних ціннісних орієнтацій, моральних та естетичних інтересів, політичних переконань. Цей процес обумовлює специфічні проблеми молоді, серед яких безробіття, залежність від батьків, відсутність власного житла та перспектив його придбання, неготовність до зрілих відносин, проблеми зі здоров'ям, високий рівень девіації, злочинності, наркоманії, проституції та інших відхилень серед молоді. У молодіжному середовищі існують різні уявлення щодо «покликання» молодих людей, їхного місця в суспільстві, моди, стилю, соціальних норм, цінностей та інтересів. Саме такі уявлення стають причиною входження молоді у субкультурний простір [4; 6]. Нестабільність, криза економіки, політичні перепетії негативно впливають на молодих людей, проблеми загострюються, ведуть до зростання відчуженості молоді від родини, держави, суспільства. Одним із шляхів вирішення цих проблем - реалізація себе у просторі молодіжних субкультур. Входження молодих людей у субкультурний простір може бути пояснений і іншими чинниками, такими як вікові та диспозиційні особливості розвитку особистості. В даній статті ми зосередили увагу на соціально-психологічних чинниках, так як на сьогодні український соціум знаходиться в стані ціннісно-нормативної дезінтеграції, соціальної аномії, коли старі норми і цінності вже не відповідають реальним відносинам, а нові ще не затвердилися [2, с. 53]. Ціннісні орієнтації молоді змінюються. Молоде

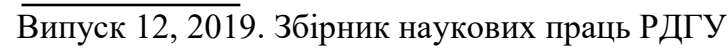


покоління опинилося перед складними і суперечливими суспільними процесами, виробляє особливий захисний механізм і власні системи цінностей.

Підкреслимо, що ту або іншу молодіжну субкультуру, незважаючи на той негатив, який вона в собі несе, не можна сприймати як щось тільки антисоціальне, як суспільне зло. Це - те поле самореалізації, яке обрали для себе молоді люди. Дорослі розмірковують про медико-біологічні причини девіацій в молодіжному середовищі і про антисоціальні впливи середовища на молодь, але часто не бачать основного джерела негативних проявів у молодих людей, яке пов'язано з тим, що в силу різних причин людина не реалізовує свої потреби, не може знайти поле своєї самореалізації. I поки вчені і практики міркують, молоді люди шукають вихід і способи реалізації цих потреб і свою «нішу», яка, на жаль, не завжди буває соціально схвалюваною іншими людьми.

Аналіз різних молодіжних субкультур свідчить, що ті чи інші види девіантної поведінки у молодих людей $є$ більшою чи меншою мірою значимим атрибутом (елементом) субкультури, який може виступати як ритуал залучення (ініціації) до субкультури, спосіб ідентифікації 3 іiі представниками, елемент символічного світу субкультури, особлива форма комунікації в співтоваристві, форма протесту по відношенню до «дорослої» культури [5, с. 172]. Молодіжна субкультура - це певне поле реалізації, що виникає як потреба у молодих людей, яке вони обирають при відсутності альтернативи, тому в процесі організації профілактики необхідне вивчення різних молодіжних субкультур з метою визначення ефективного комплексу заходів профілактики девіантної поведінки молоді. Знищити або заборонити певну субкультуру неможливо, бо певні спроби будуть породжувати певний супротив, протести. Психологічна наука покликана вивчити проблему входження молоді у субкультурний простір, забезпечити розробку і впровадження програм соціалізації молоді, які враховували б вплив субкультурного простору.

Висновки та перспективи подальших досліджень. Активне входження молоді у субкультурний простір пояснюється сучасними суспільними процесами, які характеризуються рядом радикальних змін. Ці зміни реалізуються під впливом таких чинників як перманентний нігілізм психологічна основа трансформації суспільної свідомості, постійна маніпуляція людською свідомістю як нормою суспільного життя, філософія маркетингу як творця цінностей суспільства споживання. Гостро відчуваючи такі зміни у суспільній свідомості, молоді люди усвідомлюють, що властиві їм цінності (повага один до одного, дружба, самостійність) не завжди можуть бути реалізовані у сучасному суспільстві і тому обирають субкультуру як альтернативу, як спосіб «входження у доросле життя». Узагальнення досліджень дозволяє виокремити такі соціальнопсихологічні чинники входження молоді у субкультурний простір: прагнення до самореалізації; засвоєння нових соціальних ролей; сімейні конфлікти; життєвий романтизм; протиставлення себе нормам формальної групи і конфлікти в ній тощо.

Перспективу подальших досліджень вбачаємо в питаннях організації профілактичної роботи, пошуку ефективних шляхів регулювання і мінімізації асоціальної поведінки членів різних молодіжних субкультур. Явище молодіжної субкультури не може бути витісненим із соціальної реальності, тому вдало організована взаємодія не лише забезпечить налагодження діалогу, а й сприятиме формуванню критичного мислення, ставлення молодих людей до своєї участі у молодіжних об'єднаннях, розуміння того, що цей процес короткочасний; усвідомлення негативної сутності таких об'єднань, їх критичного аналізу [1, с. 32].

\section{Список використаних джерел}

1. Артьомов П.М. Типологізація молодіжних субкультур: аналіз основних напрямків та нових засад / П.М.Артьомов // Соціологія майбутнього: Науковий журнал 3 проблем соціології молоді та студенства. - 2011. - №2. - С.32-37.

2. Павелків В.Р. Психогенеза підліткових субкультур: монографія/ В.Р.Павелків. - Київ: «Центр учбової літератури», 2018. - 280 с.

3. Павелків В.Р. Аналіз вивчення деформованої соціалізації як мотиву девіантної поведінки в умовах включення особистості до простору субкультури /В.Р.павелків // Science and Education a New Dimension. Pedagogy and Psychology, III (33), Issue: 66, 2015. - C.75 -79.

4. Парфенюк Д.В. Социально-психологическая направленность представителей молодежных субкультур: автореф. дисс.канд. психол. наук: спец. 19.00 .05 - социальная психология / Д.В. Парфенюк. - Москва, 2011. - 24 с.

5. Товканець О. Молодіжна субкультура і девіантна поведінка / О. Товканець // Науковий вісник Ужгородського нац. ун-ту. Серія : Педагогіка. Соціальна робота. - 2011. - Вип. 22. - С. 170172. - Режим доступу: http://nbuv.gov.ua/UJRN/Nvuuped_2011_22_61. 
1. Artomov P.M. Typolohizatsiia molodizhnykh subkultur: analiz osnovnykh napriamkiv ta novykh zasad / P.M.Artomov // Sotsiolohiia maibutnoho: Naukovyi zhurnal z problem sotsiolohii molodi ta studenstva. - 2011. - \#2. - S.32-37.

2. Pavelkiv V.R. Psykhoheneza pidlitkovykh subkultur: monohrafiia/ V.R.Pavelkiv. - Kyiv: «Tsentr uchbovoi literatury», 2018. - $280 \mathrm{~s}$.

3. Pavelkiv V.R. Analiz vyvchennia deformovanoi sotsializatsii yak motyvu deviantnoi povedinky v umovakh vkliuchennia osobystosti do prostoru subkultury /V.R.pavelkiv // Science and Education a New Dimension. Pedagogy and Psychology, III (33), Issue: 66, 2015. - S.75 -79.

4. Parfeniuk D.V. Sotcialno-psikhologicheskaia napravlennost predstavitelei molodezhnykh subkultur: avtoref. diss.kand. psikhol. nauk: spetc. 19.00.05 - sotcialnaia psikhologiia / D.V. Parfeniuk. Moskva, 2011. $-24 \mathrm{~s}$.

5. Tovkanets O. Molodizhna subkultura i deviantna povedinka / O. Tovkanets // Naukovyi visnyk Uzhhorodskoho nats. un-tu. Seriia : Pedahohika. Sotsialna robota. - 2011. - Vyp. 22. - S. 170-172. Rezhym dostupu: http://nbuv.gov.ua/UJRN/Nvuuped_2011_22_61.

\section{O.I. Artemova SOCIO-PSYCHOLOGICAL FACTORS OF YOUTH ENTRÉE INTO SUBCULTURAL SPACE}

The articles provides the theoretical analysis of socio-psychological factors of youth entrée into subcultural space and the influence of youth subcultures on the formation of personality; is also emphasized in the article on the necessity of developing and implementing programs of socialization of youth, which would take into account the influence of subcultural space.

The generalization of research allows distinguishing the following socio-psychological factors of youth entrée into the subcultural space: the desire for self-realization; assimilation of new social roles; family conflicts; life romanticism; opposition to the norms of the formal group and conflicts in it and so on.

The youth subculture is a certain field of fulfilment that arises as a need for youth and which is chosen in the absence of an alternative; therefore, in the process of organizing the prevention, it is necessary to study different youth subcultures in order to identify an effective set of preventive measures for deviant behaviour among young people. It is impossible to destroy or ban a particular subculture, as certain attempts will give rise to certain oppositions, protests. Psychological science is intended to study the problem of the youth entrée into the subcultural space. The phenomenon of youth subculture can not be displaced from social reality, therefore, a well-organized interaction will not only ensure the establishment of a dialogue, but will also contribute to the formation of critical thinking, the attitude of young people to their participation in youth associations.

Key words: youth subculture, subculture space, deviant behavior, socio-psychological factors.

УДК 159.922.8: [159.98:617]-059.876

М. Ф. БАБІЙ

DOI: https://doi.org/10.35619/prap_rv.vi12.40

\section{РОЗВИТОК ІНТЕЛЕКТУАЛЬНИХ ЗДІБНОСТЕЙ У ПРОЦЕСІ НАВЧАЛЬНО-ІГРОВОЇ ВЗАЕМОДІї}

Стаття присвячена проблемі розвитку інтелектуальних здібностей у дітей молодшого шкільного віку. Шлях їі вирімення лежсить через активну форму психодидактичної взаємодії. Такою ми вбачаємо дидактичну гру. В ній гармонійно поєднується гра та навчання.

Роблячи цей вибір, ми виходили з тих міркувань, щяо у перших класах відбувається адаптація до навчального процесу, а також зміна провідної діяльності. У иьому контексті найкраще підходить дидактична гра, яка забезпечує плавний перехід до нової провідної діяльності - навчання. Відповідно, запропонована модель педагогічної взаємодії це, комплекс елементів навчально-ігрової взаємодії спрямований на розвиток пізнавальної сфери та інтелектуальних здібностей дітей молодшого шкільного віку.

Ключові слова: мотив, мотивачія, провідна діяльність, гра, дидактична гра, навчання, інтелектуальні здібності, генезис, навчальні дії .

Статья посвящена проблеме развития интеллектуальных способностей у детей младшего школьного возраста. Путь ее решения лежит через активную форму психодидактического взаимодействия. Такой мы видим дидактическую игру. В ней гармонично сочетается игра и обучения.

Випуск 12, 2019. Збірник наукових праць РДГУ 